\title{
Correlation between Soil Mycoflora and Productivity under Influence of Organic and Inorganic Inputs Applied Field of Cajanus cajan.
}

\author{
Shaikh, N. F. ${ }^{1}$, Gachande B. D. ${ }^{2}$ \\ Botany Research Laboratory and Plant Disease Clinic, N.E.S. Science College, Nanded-431605 (MS), India
}

\begin{abstract}
In present investigation a field experiment was conducted in a Cajanus cajan field during 2010-2013, to study the effect of various fermented liquid organic inputs and inorganic inputs on rhizosphere and Non-rhizosphere mycoflora population and yield. The soil rhizosphere and Non-rhizosphere mycoflora population was studied by using serial dilution technique. Result observed that application of organic inputs like Farm yard manure, Beejamruth and Jeevamruth increases rhizosphere and Non-rhizosphere fungal population in terms of colony forming unit (CFU) in organic field. The application of inorganic inputs lowers the rhizosphere and Nonrhizosphere mycoflora population (CFU) compare to organic field of Cajanus cajan. The yield obtained in organic field was higher than inorganic field and it is signifintly correlated with the mycoflora population.
\end{abstract}

Keywords: Cajanus cajan, mycoflora, Yield, Organic and Inorganic inputs.

\section{Introduction}

Type of cultivation and crop management practices found to have greater influence on the activity of soil microflora $(\mathrm{Mc}$ Gill et al., 1980). Dynamics of biological activity of soil and seasonal variation of soil microorganisms may be the results of the changes occurring in soil chemistry. The chemical properties of soil influence the numerical presence of microorganisms (Oneț et al., 2011)

Now a day's farmers were extensively using different External agricultural inputs like inorganic fertilizers such as urea, ammonium nitrate, sulfates, and phosphates; organic fertilizers such as animal manures (FYM), vermicompost and plant composts; various other organic products such as humic acids and microbial inoculants, and pesticides including herbicides, insecticides, nematicides, fungicides, veterinary health products, and soil fumigants. All these inputs were used to maximizing crop productivity and economic returns.

The different organic and inorganic inputs present in the soil have a direct effect on the microbial population of the soil. During past decades, conventionally managed agricultural system has used inorganic fertilizer and pesticides to improve crop productivity. This intensive use of agrochemicals will definitely reduce the biodiversity, increase irreversible erosion of soil and reduce soil organic matter (Dick, 1992; Schiavon et al., 1995).

To overcome the adverse effect of chemical fertilizers farmers are turning towards organic farming. Pure Organic Farming accounts complete exclusion of inorganic fertilizers and pesticides, but advocates the use of organic manures and biological pest control methods. The result of some investigation indicate that, This system can reduce some negative effects attributed to conventional agriculture and has potential benefits in enhancing soil quality (Mader et al., 2002). Application of high $\mathrm{N}$ rates of chemical fertilization result in decline of some beneficial microorganisms (Barabasz et al., 2002). While application of different organic inputs like plant compost, vermicompost, farm yard manure and integrated plant compost results in increase in rhizosphere microbial population (Das and Dkhar 2012). Addition of organic amendments increases microbial biomass and microbial activity compared to conventional agricultural system (Gelsomino et al., 2004).

The application of FYM, vermicompost and GLM in organic nutrient management practices significantly increases in yield of soybean, groundnut and chilli and it is superior over inorganic nutrient management (Vidyavathi et al., 2011). The combinations of Beejamruth+ Jeevamruth + Panchagavya were best treatment and resulted in significantly highest yield as compared to RDF alone in tomato (Gore and Sreenivasa, 2011).

Low organic carbon content in the soil seriously affects the growth of microbes. Therefore, addition of organic materials such as manure and crop straw is essential for improving soil fertility and increasing rice crop yield as well as increasing microbial biomass and diversity (Zhong and Cai, 2007).

The present investigation was carried out to study the Correlation between soil mycoflora and productivity under influence of organic and inorganic inputs applied field of Cajanus cajan during the period 2010-2013.

\section{Materials and Methods}

\subsection{Experimental Study Site}

Agricultural fields of Nanded district of Maharashtra were selected for the study of rhizosphere and Non-rhizosphere mycoflora populations and productivity (yield) under the influence of organic and inorganic inputs applied field of Cajanus cajan during the period 2010-2013.The selected experimental organic field was supplied with farm yard manure and organic liquid like Jeevamruth and Beejamruth 


\section{International Journal of Science and Research (IJSR) \\ ISSN (Online): 2319-7064 \\ Index Copernicus Value (2013): 6.14 | Impact Factor (2014): 5.611}

(Palekar, 2006).The Jeevamruth applied to field crop and Beejamruth applied to seed. The inorganic field supplied with regular chemical fertilizers.

\subsection{Collection of soil samples}

Rhizosphere soil samples were collected from organic and inorganic crop fields of Cajanus cajan crop by digging out soil around the rhizosphere area up to $20 \mathrm{~cm}$ from plant to a dimension of $15 \mathrm{~cm}$ height and $7 \mathrm{~cm}$ diameter. The five samples were collected from sampling site from each selected crop field and mixed together into a single. Similar sampling was taken from Non-rhizosphere zone $(25-40 \mathrm{~cm}$ away from the plant). These soil samples were collected in sterile polythene bags and brought to the laboratory.

\subsection{Enumeration of Soil Fungal Population}

The rhizosphere and Nom-rhizosphere fungi were enumerated by Serial dilution method (Waksman, 1992). The collected soil samples from both the organic and inorganic inputs applied field were used for preparation of different serial Dilutions such as $10^{-2}, 10^{-3}, 10^{-4}$, and $10^{-5}$. Then transferred $1 \mathrm{ml}$ aliquots from each dilution were used to count the fungal population on Martins Rose Bengal Agar Medium, potato dextrose agar and Czapek's Dox Agar. One percent streptomycin solution was added to the medium before pouring into petriplates for preventing bacterial growth and plates were kept for incubation at $28{ }^{\circ} \mathrm{C}$ for $4-7$ days for fungi. After 6 days of incubation the different colonies were counted from different organic and inorganic soil plates.

\subsection{Statistical Analysis}

The quantitative analysis of fungal population was studied at $10^{-3}$ dilution. The percentage contribution of each colony forming units (CFU) of different fungal isolate was calculated by using the formula.

\section{CFU/g dry soil = Mean plate count X dilution factor dry weight of soil}

\subsection{Collection of Yield Data}

The yield data of selected crops were collected for three successive years of selected crop from both organic and inorganic field during 2010-2011, 2011-2012 and 2012-2013 in terms yield $\mathrm{q} /$ acre.

\subsection{Correlation between Population of soil mycoflora \& yield.}

The collected yield data of selected different crop plants from organic and inorganic fields were correlated with mycoflora population (colony forming unit) at $10^{-3}$ dilution with the help of SPSS statistical software.

\section{Results and Discussion}

The results on rhizosphere and Non-rhizosphere mycoflora population and yield of Cajanus cajan in organic and inorganic field shows there is increase in rhizosphere and Non-rhizosphere mycoflora population and yield in organic inputs applied field compared to inorganic inputs applied field.

In organic field, Population of rhizosphere fungi ranged from $36.8 \times 10^{-3}$ to $51.2 \times 10^{-3} \mathrm{CFU} / \mathrm{g}$ of soil $(2010-11)$, $38.4 \times 10^{-3}$ to $52.0 \times 10^{-3} \mathrm{CFU} / \mathrm{g}$ of soil (2011-12) and $43.6 \times 10^{-}$ 3 to $54.3 \times 10^{-3} \mathrm{CFU} / \mathrm{g}$ of soil (2012-13). In inorganic field, Population of rhizosphere fungi ranged from $23.2 \times 10^{-3}$ to $36.0 \times 10^{-3} \mathrm{CFU} / \mathrm{g}$ of soil $(2010-11), 18.4 \times 10^{-3}$ to $30.4 \times 10^{-}$ ${ }^{3} \mathrm{CFU} / \mathrm{g}$ of soil (2011-12) and $15.2 \times 10^{-3}$ to $28.4 \times 10^{-3} \mathrm{CFU} / \mathrm{g}$ of soil (2012-13). (Table.1)

In organic field, Population of Non-rhizosphere fungi ranged from $25.6 \times 10^{-3}$ to $36.0 \times 10^{-3} \mathrm{CFU} / \mathrm{g}$ of soil $(2010-11)$, $27.2 \times 10^{-3}$ to $46.3 \times 10^{-3} \mathrm{CFU} / \mathrm{g}$ of soil $(2011-12)$ and $32.6 \times 10^{-}$ 3 to $52.6 \times 10^{-3} \mathrm{CFU} / \mathrm{g}$ of soil (2012-13). In inorganic field, Population of Non-rhizosphere fungi ranged from $10.4 \times 10^{-3}$ to $24.8 \times 10^{-3} \mathrm{CFU} / \mathrm{g}$ of soil $(2010-11), 11.2 \times 10^{-3}$ to $20.8 \times 10^{-}$ ${ }^{3} \mathrm{CFU} / \mathrm{g}$ of soil $(2011-12)$ and $10.3 \times 10^{-3}$ to $21.3 \times 10^{-3} \mathrm{CFU} / \mathrm{g}$ of soil (2012-13). (Table.2)

It is observed that application of FYM ( $5 \mathrm{t} / \mathrm{ha})$ to soybean field had significantly increased the fungi (22.21 and 27.25 CFU $\times 10^{3} / \mathrm{g}$ ) in the soybean field at 30 and 60 DAS, respectively (Meena and Ghasolia (2013). Study revealed that the fungal population count was observed maximum $\left(4.6 \times 10^{-3} \mathrm{CFU} \mathrm{m} \mathrm{m}^{-1}\right)$ in organic treatment than in inorganic $\left(3.6 \times 10^{-3} \mathrm{CFU} \mathrm{m}^{-1}\right)$ treatment (Tanvi et al., 2015).addition of various organic manures and microbial inoculants on fertility of mulberry garden enhances fungal population $\left(37.66 \times 10^{3} \mathrm{CFU} / \mathrm{g}\right.$ soil (Shashidhar et al., 2009).Inorganic fertilizer to crop field significantly lowers the rhizosphere microbial population and diversity (Nelson and Mele, 2006).The organic inputs like Panchagavya and Beejamruth seed treatment increases rhizosphere microbial population (Shubha et al., 2014). the application of two commonly used herbicides (atrazine and atrazine + metolachlor) on nontarget soil of maize field resulted in decreases in microbial counts (Ayansina and Oso 2006).

The data presented in table shows the application of organic inputs like farm yard manure and Jeevamruth during the period 2010-13 in organic field of Cajanus cajan increases yield. While during 2010-13 in inorganic field there was decrease or increasing yield means there is no continuity. In organic farming of Cajanus cajan the recorded yield in 2010-11 was (12.2 q/acre), 2011-12 was (14.6 q/acre) and 2012-13 was (16.4 q/acre). In inorganic farming of Cajanus cajan the recorded yield in 2010-11 was (9.2 q/acre), 2011 12 was (8.6 q/acre) and 2012-13 was (10.3 q/acre). (Table.3)

Reported that, in organic farming there is increasing yield year by year and decrease in inorganic fields year to year. Yields in organic system increase up to $28-32 \%$ than those in the conventional plots (Padmavathy and Poyyamoli 2011). Application of organic inputs like (FYM, Poultry manure, Panchagavya, Beejamruth and Jeevamruth) with or without biofertilizers (Azospirillum + Phosphorus solubilizing bacteria) results in beneficial effect on growth and yield attributes of onion (Praveenkumar and Allolli 2010). application of organic inputs like Jeevamruth and Panchagavya were significantly increases grain yield (3387 $\mathrm{kg} \mathrm{ha}$ ) and Straw yield (4632 kg ha') (Divya and Babalad 


\section{International Journal of Science and Research (IJSR) \\ ISSN (Online): 2319-7064 \\ Index Copernicus Value (2013): 6.14 | Impact Factor (2014): 5.611}

2012). most European studies of organic farming found that decrease in crop yields in organic farming compare to conventional farming. While some American studies have reported similar yields in organic farming and inorganic farming of tomatoes and corn (Poudel et al., 2002). The effect of farm yard manure with Jeevamruth on yield and economics result revealed that, application of farm yard manure at the rate $7.5 \mathrm{t} \mathrm{ha}^{-1}$ with Jeevamruth recorded highest (Rs.27,384 ha ${ }^{-1}$ ) net profit compare to the treatment 100 per cent Recommended dose of fertilizer (RDF) (Rs. $25,475 \mathrm{ha}^{-1}$ ) in Sunflower (Helianthus annus L.) (Manjunathas et al., 2009).

For soil mycoflora population in organic field there is a strong positive correlation between soil mycoflora and yield in an organic farm. Thus there is strong evidence from sample values to beliieve that in organic fields as soil mycoflora population increases yield also increases. For soil mycoflora population in inorganic field there is a moderate negative correlation between soil mycoflora and yield in inorganic farm. The data shows for 2010-2013. It is found that, organic inputs applied to soil gradually changes in microbial community structure which responsible for enhancing gradual improvement in soil quality finally increases yield (Visser and Parkinson 1992). Application of poultry litter (PL), as a fertilizer to cotton field, results in increase soil fungal population levels over time. It determines relationships of fungal population levels to soil nutrient contents and cotton growth and yield (Pratt and Tewolde, 2009). (Table.4)

\section{Conclusion}

The organic inputs like farm yard manure, Jeevamruth and Beejamruth increases the soil mycoflora population and yield compared to inorganic inputs applied field which adversely affect mycoflora population and yield it means there is positive correlation between fungal population and yield of Cajanus cajan in organic field compare to inorganic field.

The Increase in soil mycoflora population enhances nutrient availability to crop ultimately increases growth and yield of crop plants. From this result we can conclude that organic liquid manure can be used for increase in microbial population and yield of crops for sustainable eco-friendly development.

\section{Acknowledgement}

The authors are grateful to the Department of Botany, N.E.S. Science College, Nanded for providing necessary laboratory facilities. The first author also grateful to Maulana Azad National Fellowship, New Delhi for providing financial support to conduct this research work.

Table 1: Population of Rhizosphere mycoflora (x $10^{-3} \mathrm{CFU} / \mathrm{g}$ soil) in organic and Inorganic field of Cajanus Cajan.

\begin{tabular}{|c|c|c|c|c|c|c|c|}
\hline Sr.No & Months & \multicolumn{3}{|c|}{ Organic field } & \multicolumn{3}{c|}{ Inorganic field } \\
\hline & & $2010-2011$ & $2011-2012$ & $2012-2013$ & $2010-2011$ & $2011-2012$ & $2012-2013$ \\
\hline 1 & Jun & 51.2 & 47.2 & 54.3 & 28.8 & 26.8 & 28.4 \\
\hline 2 & July & 43.2 & 44.8 & 48.2 & 25.2 & 21.6 & 20.4 \\
\hline 3 & Aug & 36.8 & 38.4 & 43.6 & 28.0 & 28.8 & 27.6 \\
\hline 4 & Sep & 39.2 & 40.8 & 45.3 & 23.2 & 18.4 & 16.8 \\
\hline 5 & Oct & 45.2 & 48.8 & 50.2 & 30.4 & 25.2 & 23.2 \\
\hline 6 & Nov & 49.6 & 52.0 & 54.3 & 33.6 & 30.4 & 24.0 \\
\hline 7 & Dec & 40.8 & 46.4 & 49.8 & 36.0 & 23.2 & 19.4 \\
\hline 8 & Jan & 37.6 & 41.6 & 45.4 & 26.4 & 19.2 & 15.2 \\
\hline & Average & 42.95 & 45.00 & 48.88 & 28.95 & 24.20 & 21.87 \\
\hline & S.D & \pm 5.379 & \pm 4.520 & \pm 4.046 & \pm 4.275 & \pm 4.371 & \pm 4.784 \\
\hline
\end{tabular}

Table 2: Population of Non-Rhizosphere mycoflora (x $10^{-3} \mathrm{CFU} / \mathrm{g}$ soil) in organic and Inorganic field of Cajanus cajan.

\begin{tabular}{|c|c|c|c|c|c|c|c|}
\hline S. No & Months & \multicolumn{3}{|c|}{ Organic field } & \multicolumn{3}{c|}{ Inorganic field } \\
\hline & & $2010-2011$ & $2011-2012$ & $2012-2013$ & $2010-2011$ & $2011-2012$ & $2012-2013$ \\
\hline 1 & Jun & 36.0 & 33.6 & 40.4 & 21.6 & 19.2 & 21.3 \\
\hline 2 & July & 31.2 & 27.2 & 32.6 & 18.4 & 14.4 & 15.2 \\
\hline 3 & Aug & 25.6 & 29.2 & 38.2 & 15.2 & 20.8 & 16.5 \\
\hline 4 & Sep & 28.8 & 36.6 & 44.5 & 16.8 & 11.6 & 10.3 \\
\hline 5 & Oct & 34.0 & 42.3 & 50.3 & 20.8 & 16.8 & 11.6 \\
\hline 6 & Nov & 29.6 & 34.5 & 43.5 & 10.4 & 14.4 & 12.3 \\
\hline 7 & Dec & 36.0 & 46.3 & 52.6 & 24.8 & 11.2 & 10.8 \\
\hline 8 & Jan & 27.2 & 35.8 & 47.8 & 12.8 & 12.8 & 12.4 \\
\hline & Average & 31.05 & 35.68 & 43.73 & 17.60 & 15.15 & 13.80 \\
\hline & S.D & \pm 3.953 & \pm 6.291 & \pm 6.596 & \pm 4.780 & \pm 3.503 & \pm 3.699 \\
\hline
\end{tabular}

Table 3: Comparison between crop Production in Organic and Inorganic field of Cajanus cajan during 2010-2013.

\begin{tabular}{|c|c|c|c|}
\hline Sr. No & Field & Organic yield Q/acre & Inorganic yield Q/acre \\
\hline 1 & $2010-2011$ & 12.2 & 9.2 \\
\hline 2 & $2011-2012$ & 14.6 & 8.6 \\
\hline 3 & $2012-2013$ & 16.4 & 10.3 \\
\hline
\end{tabular}

Volume 5 Issue 1, January 2016 
International Journal of Science and Research (IJSR)

ISSN (Online): 2319-7064

Index Copernicus Value (2013): 6.14 | Impact Factor (2014): 5.611

Table 4: Correlation between population of soil mycoflora and yield in Cajanus cajan.

\begin{tabular}{|c|c|c|c|c|}
\hline Year & \multicolumn{2}{|c|}{ Organic field } & \multicolumn{2}{c|}{ Inorganic field } \\
\hline & Rhizosphere & Non-Rhizosphere & Rhizosphere & Non-Rhizosphere \\
\hline $\begin{array}{c}\text { Over period } 2010-13 \\
\text { (3 years) }\end{array}$ & 0.967 & 0.972 & -0.476 & -0.502 \\
& Sig $(2$ tailed $)$ & Sig $(2$ tailed $)$ & Sig $(2$ tailed $)$ & Sig $(2$ tailed $)$ \\
0.165 & 0.150 & 0.684 & 0.665 \\
\hline
\end{tabular}

\section{References}

[1] Ayansina, A. D. V. and Oso, B. A. (2006). Effect of two commonly used herbicides on soil microflora at two different concentrations. African Journal of Biotechnology, 5 (2):129-132.

[2] Barabasz W., Albińska D., Jaskowska M., and Lipiec J. (2002). Biological Effects of Mineral Nitrogen Fertilization on Soil Microorganisms. Polish Journal of Environmental Studie, 11(3):193-198.

[3] Das Bibhuti B. and Dkhar M. S. (2012). Organic Amendment Effects on Microbial Population and Microbial Biomass Carbon in the Rhizosphere Soil of Soybean. Communications in Soil Science and Plant Analysis, 43:1938-1948.

[4] Dick R.P. (1992). A review: long-term effects of agricultural systems on soil biochemical and microbial parameters. Agriculture, Ecosystems and environment, 40:25-36.

[5] Divya Sahare and Babalad H. B. (2012). Organic nutrient management practices for sustainable aerobic rice production. Karnataka J. Agric. Sci., 25 (4):581.

[6] Gelsomino, C. C., Ambrosoli A., Minati R and Ruggiero P. (2004). Functional and molecular responses of soil microbial communities under differing soil management practice. Soil Biology and Biochemistry, 36:1873-1883.

[7] Gore Nileema S. and Sreenivasa M. N. (2011). Influence of liquid organic manures on growth, nutrient content and yield of tomato (Lycopersicon esculentum Mill.) in the sterilized soil. Karnataka J. Agric. Sci., 24 (2): 153-157.

[8] Mader, P. Fliessbach, A. Dubois, D. Gunst, L. Fried, P. and Niggli, U. (2002). Soil fertility and biodiversity in Organic Farming. Science, 296:16941697.

[9] Manjunathas G. S.., Upperi N., Pujari B. T., yeledahalli A. and Kuligod V. B.(2009). Effect of farm yard manure treated with jeevamruth on yield attributes, yield and economics of Sunflower (Helianthus annuus L.). Karnataka J. Agric. Sci., 22(1):198-199.

[10] Mc.Gill, W.B., Cannon, K.R., Robertson, J.A and Coock, G.D. (1980). Dynamics of soil microbial biomass and water stable organic carbon in Breton.L after fifty years of Cropping to two rotations, Canadian journal of soil science, 66: 1-19.

[11] Meena Suresh and Ghasolia R. P. (2013). Effect of phosphate solubilizers and FYM on microbial Population of soybean field [Glycine $\max ($ L.) Merrill]. The Bioscan, 8(3): 965-968.

[12] Nelson, D.R., and Mele, P.M. (2006). Subtle changes in rhizosphere microbial community structure in response to increased boron and sodium chloride concentrations. Soil Biology \& Biochemistry, 39: 340351.

[13] Oneț Aurelia, Domuța Cornel, Brejea Radu and Oneţ Cristian. (2011). Study on the dependence between seasonal variation of microorganisms and chemical properties of Haplic Luvisol Analele Universităţii din Oradea, Fascicula Protecţia Mediului Vol. XVI

[14] Padmavathy A. and Poyyamoli G. (2011). Effects of conventional and organic management strategies on soil quality and Biodiversity in Agricultural fields of Bahour, Puducherry, India. American-Eurasian J. Agric. \& Environ. Sci., 10(4): 644-652.

[15] Palekar, S. (2006): Text book on Shoonya Bandovalada naisargika Krushi, published by Swamy Anand, Agri Prakashana, Bangalore.

[16] Poudel, D.D., Horwath, W.R., Lanini, W.T., Temple, S.R. and van Bruggen, A.H.C. (2002). Comparison of soil $\mathrm{N}$ availability and leaching potential, crop yields and weeds in organic, low input and conventional systems in northern California. Agriculture, Ecosystems and Environment, 90: 125137.

[17] Pratt R.G. and Tewolde H. (2009). Soil fungal population levels in cotton fields fertilized with poultry litter and their relationships to soil nutrient concentrations and plant growth parameters. Applied soil ecology, 41:41-49.

[18] Praveenkumar, D. A. and Allolli, T. B. (2010). Studies on organic farming practices in onion (Allium cepa var. cepa). Karnataka J. Agric. Sci., 23 (5): 859.

[19] Schiavon, M., Perringanier, C., and Portal, J.M. (1995). The pollution of water by pesticides state and origin. Agronomie, 15:157-170.

[20] Shashidhar, K. R., Narayanaswamy T. K., Bhaskar R. N., Jagadish B. R. and Mahesh M. (2009). Influence of organic based nutrients on soil Health and mulberry (Morus indica L.) Production e Journal of Biological Sciences, 1(1):94-100.

[21] Shubha S., Devakumar N., Rao G.G.E. and Gowda S.B. (2014). Effect of Seed treatment, Panchagavya application and Organic Farming Systems on Soil microbial population, Growth and Yield of Maize. Proceedings of the 4th ISOFAR Scientific Conference. 'Building Organic Bridges', at the Organic World Congress 2014, 13-15 Oct., Istanbul, Turkey (23483).

[22] Tanvi Kapoor, Ramesh C. Chauhan, Sudha Sambyal Malik, Raashee Abhilashi and Natasha Sharma. (2015). Impact of Different Farming Systems on the Soil Quality under Sub Humid Agroecosystem of Zone-II of Himachal Pradesh. The 2nd Int Conf on Bio-resource and Stress Management during 7-10th Jan 2015 at PJTSAU, Rajendranagar, Hyderabad, India. 


\section{International Journal of Science and Research (IJSR) \\ ISSN (Online): 2319-7064}

Index Copernicus Value (2013): 6.14 | Impact Factor (2014): 5.611

[23] Vidyavathi, G. S. D, Babalad H. B., Hebsur N. S., Gali S. K., Patil S. G. and Alagawadi A. R. (2011). Nutrient status of soil under different nutrient and crop management practices. Karnataka J. Agric. Sci., 25 (2): 193-198.

[24] Visser, S and Parkinson, D. (1992). Soil biological criteria as indicators of soil quality: soil microorganisms. Am. J. Alt. Agric., 7:33-37.

[25] Waksman, S. A. (1992). A method for counting the numbers of fungi in the soil. J. Bot.7:339-341.

[26] Zhong W.H. and Cai Z.C. (2007). Long-term effects of inorganic fertilizers on microbial biomass and community functional diversity in a paddy soil derived from quaternary red clay. Applied soil ecology, 36:8491. 